\title{
PREDICTIVE MODEL TO THE BOND STRENGTH OF FRP-TO-CONCRETE UNDER DIRECT PULLOUT USING GENE EXPRESSION PROGRAMMING
}

\author{
Yasmin MURAD $\mathbb{D}^{*}$, Ahmed ASHTEYAT, Rozan HUNAIFAT \\ University of Jordan, Queen Rania str., Amman, Jordan
}

Received 01 March 2019; accepted 13 May 2019

\begin{abstract}
Gene expression programming (GEP) is used in this research to develop an empirical model that predicts the bond strength between the concrete surface and carbon fiber reinforced polymer (CFRP) sheets under direct pull out. Therefore, a large and reliable database containing 770 test specimens is collected from the literature. The gene expression programming model is developed using eight parameters that predominantly control the bond strength. These parameters are concrete compressive strength, maximum aggregate size, fiber reinforced polymer (FRP) tensile strength, FRP thickness, FRP modulus of elasticity, adhesive tensile strength, FRP length, and FRP width. The model is validated using the experimental results and a statistical assessment is implemented to evaluate the performance of the proposed GEP model. Furthermore, the predicted bond results, obtained using the GEP model, are compared to the results obtained from several analytical models available in the literature and a parametric study is conducted to further ensure the consistency of the model by checking the trends between the input parameters and the predicted bond strength. The proposed model can reasonably predict the bond strength that is most fitting to the experimental database compared to the analytical models and the trends of the GEP model are in agreement with the overall trends of the analytical models and experimental tests.
\end{abstract}

Keywords: bond strength, gene expression programming, FRP, concrete, large data base.

\section{Introduction}

Strengthening and repairing reinforced concrete structures using externally bonded fiber reinforced polymer (FRP) plates or sheets have become a widely accepted solution. Fibers with their unique properties have preferences over the other strengthening materials. Fiber composites are light-weight materials that are resistant to corrosion, adaptable for use in different configuration and have high tensile strength. However, the efficiency of FRP depends significantly on the bond between FRP and concrete which is controlled by several parameters such as concrete compressive strength, maximum aggregate size, FRP tensile strength, FRP thickness, FRP modulus of elasticity, adhesive tensile strength, FRP length and width, skilled labour, well treated and un-damaged concrete surface and epoxy quality.

Bond failure is the most common type of failure in RC members that strengthened with external FRP sheets or plates. Several experimental studies have been carried out to control bonding problems between the concrete surface and FRP sheets. Ozbakkaloglu and Saatcioglu (2009) have used FRP anchors to overcome delamination problems en- countered in surface bonded FRP sheets. They have found that FRP anchors can increase the pull out capacities and hence can delay the delamination of externally bonded FRP sheets. They have found that the bond capacity is controlled by the diameter, length, and the angle of inclination of the anchors. Murad (2018a, 2018b) has found that CFRP sheets' orientation angle has significant effect on the peak load and deflection of reinforced concrete members. Ozbakkaloglu, Fang, and Gholampour (2017) have studied the effect of fiber-reinforced polymer (FRP) anchor configuration on the behavior of FRP plates externally bonded on concrete members. They have found that the number and configuration of anchors can significantly influence the load-slip behaviours of FRP plates. They have shown that FRP plates with a longitudinal anchor configuration develop higher maximum strains than those of plates with a transverse anchor configuration.

Several experimental studies have been conducted to investigate the parameters that significantly influence the bond strength between concrete and carbon fiber reinforced polymer (CFRP) sheets. It is found that concrete

${ }^{*}$ Corresponding author. E-mail: y.murad@ju.edu.jo 
strength has a minor effect on the bond strength while the bond strength increases by the increment of bond width (Woo \& Lee, 2010). Other researchers have found that concrete strength is the key to the bond property (Ming \& Ansari, 2004). Al-Rousan, Haddad, and Al-Halboni (2015) have shown that the effect of aggregate type is insignificant while there is a slight increase in the bond strength by increasing the aggregate size. They have also reported that the bond strength increases by increasing concrete compressive strength. They have also found that the bond strength increases by decreasing $\mathrm{w} / \mathrm{c}$ ratio while the bond strength decreases by increasing bond length and bond width. Iqbal, Ullah, and Ali (2018) have found that there is a slight increase in compressive and splitting tensile strength with the decrease of maximum aggregate size. Thus, increasing concrete compressive strength may result in increasing the bond strength while increasing the maximum aggregate size may result in decreasing the bond strength. Czaderski, Soudki, and Motavalli (2010) have found that the bond strength decreases with increasing fiber stiffness and they have also shown that fiber to concrete width ratio has a significant effect on the bond behaviour. Haddad, Al-Rousan, and Almasry (2013) have found that high temperature (more than $400{ }^{\circ} \mathrm{C}$ ) has an adverse effect on bond strength between fiber and concrete where bond strength is reduced to $64 \%$. Irshidat and Al-Saleh (2016) have found that the bond behaviour between concrete and fiber is influenced by bond length and width. Pan and Leung (2007) have found that concrete compressive or splitting tensile strength has a minor effect on the bond behaviour between FRP and concrete.

Although there are some experimental programs and analytical models that investigate the parameters that influence the bond strength between fibers and concrete surface, there is still lack of an accurate formulation that can predict the bond strength between concrete and CFRP. Empirical modelling based on classical regression techniques, which work on the basis of predefined functions, are generally used to simulate the experimental behaviour of concrete. Regression analyses are performed after defining functions. Furthermore, modern soft computing applications such as Gene Expression Programming (GEP) and Artificial Neural Network (ANN) have been used recently to predict the behaviour of concrete by developing explicit formulations (Cevik \& Sonebi, 2008; Sonebi \& Cevik, 2009). GEP approach does not specify a predefined function but it adds or deletes various combinations of parameters to be considered for the formulation that best fits the experimental results (Cevik \& Sonebi, 2008; Sonebi \& Cevik, 2009). Therefore, GEP can be considered superior to regression techniques and neural networks. GEP is an efficient tool in determining explicit formulations for the experimental results including multivariate parameters for the case where analytical expressions are not available (Cevik \& Sonebi, 2008; Sonebi \& Cevik, 2009). This study proposes a new equation that can predict bond strength between CFRP sheets and the concrete surface under di- rect pull out using gene expression programming (GEP) based on a large and reliable experimental database that collected from the literature. A comparison is also made between the bond strength predicted using the GEP model and the results obtained using some existing analytical models available in the literature. Finally, a parametric study is conducted to check the sensitivity of the proposed GEP model to the selected input parameters.

\section{Experimental database}

The proposed GEP model is developed based on a large and reliable experimental database available in the literature. The models are trained and tested using 770 data test points collected from different 27 experimental programs. The experimental database is collected from the tests that were conducted to measure the bond strength between CFRP sheets and the concrete surface under direct tension. Table A.1 in the Appendix summarizes a sample of the experimental training database from the collected specimens (Woo \& Lee, 2010; Ming \& Ansari, 2004; Mazzotti, Ferracuti, \& Bilotta, 2012; Al-Allaf, Weekes, Augusthus-Nelson, \& Leach, 2016; Ali-Ahmad, Subramaniam, \& Ghosn, 2006; Al-Rousan et al., 2015; Biolzi, Ghittoni, Fedele, \& Rosati, 2013; Czaderski et al., 2010; Wan, Jiang, \& Wu, 2018; Ghorbani, Mostofinejad, \& Hosseini, 2017; Haddad et al., 2013; Haddad, Al-Rousan, Ghanma, \& Nimri, 2015; Haddad \& Al Dalou, 2018; Hadigheh, Gravina, \& Setunge, 2015; Hosseini \& Mostofinejad, 2013, 2014; Irshidat \& Al-Saleh, 2016; Ko, Matthys, Palmieri, \& Sato, 2014; Mostofinejad, M. H. Mofrad, Hosseini, \& H. H. Mofrad, 2018; Nigro, Di Ludovico, \& Bilotta, 2011; Pan \& Leung, 2007; Serbescu, Guadagnini, \& Pilakoutas, 2013; Sharma, Mohamed Ali, Goldar, \& Sikdar, 2006; Toutanji \& Ortiz, 2001; Toutanji, Saxena, Zhao, \& Ooi, 2007; Wu \& Jiang, 2013; Yao, Teng, \& Chen, 2005). The training and testing or validation data are randomly selected from these data where $63 \%$ of the data set is used for training while $37 \%$ is used for testing and validation. Based on the experimental results available in the literature, the bond strength between CFRP sheets and concrete surface is predominantly controlled by eight main parameters that are selected to develop the GEP model. These parameters are: concrete compressive strength $f_{c}^{\prime}$, maximum aggregate size $(D)$, FRP tensile strength $\left(f_{f t}\right)$, FRP thickness $(t)$, FRP modulus of elasticity $\left(E_{f}\right)$, adhesive tensile strength $\left(f_{A t}\right)$, FRP length $\left(l_{f}\right)$ and FRP width $\left(b_{f}\right)$.

\section{Existing analytical models for predicting bond strength}

The bond strength between FRP and concrete surface is predicted in this research using various analytical models available in the literature and then compared to the values obtained from the GEP model. The equations of the selected analytical models are illustrated in Eqn (1) to Eqn (10). 
Model by Van Gemert (1980):

$$
P_{u}=0.5 \cdot b_{f} \cdot l_{f} \cdot f_{c t} \text {. }
$$

Model by Tanaka (1996):

$$
P_{u}=\left(6.13-\ln l_{f}\right) \cdot b_{f} \cdot l_{f} \text {. }
$$

Model by Yoshizawa and Wu (1997):

$$
P_{u}=5.88 \cdot l_{b}^{-0.669} \cdot b_{f} \cdot l_{f} \text {. }
$$

Model by Maeda, Asano, Sato, Ueda, and Kakuta (1999):

$$
P_{u}=110.2 \cdot 10^{-6} \cdot E_{f} \cdot t_{f} \cdot b_{f} \cdot l_{e} .
$$

Model by Khalifa, Gold, Nanni, and M.I. (1998):

$$
P_{u}=110.2 \cdot 10^{-6} \cdot\left(\frac{f_{c}^{\prime}}{42}\right)^{2 / 3} E_{f} \cdot t_{f} \cdot b_{f} \cdot l_{e} .
$$

Model by Adhikary and Mutsuyoshi (2001):

$$
P_{u}=b_{f} \cdot l_{f} \cdot\left(0.25 f_{c}^{\prime 2 / 3}\right) \text {. }
$$

Model by Yang, Yue, and $\mathrm{Hu}$ (2001), cited from $\mathrm{Lu}$, Teng, Ye, and Jiang (2005):

$$
P_{u}=\left(0.5+0.08 \cdot \sqrt{\frac{E_{f} t_{f}}{1000}} b_{f} \cdot l_{e} \cdot f_{c t}\right) .
$$

Model by Izumo, Saeki, Fukao, and Horiguchi (1999), cited from Japan Concrete Institute [JCI] (2003):

$$
P_{u}=\left(3.8 f_{c}^{\prime \frac{2}{3}}+15.2\right) \cdot b_{f} \cdot l_{b} \cdot E_{f} \cdot t_{f} \cdot 10^{-3} \text {. }
$$

Model by Iso (JCI, 2003):

$$
P_{u}=b_{f} \cdot l_{e} \cdot 0.93 \cdot f_{c}^{\prime} 0.44 \text {. }
$$

Sato, Asano, and Ueda (2001), cited from JCI (2003):

$$
P_{u}=\left(b_{f}+7.4\right) \cdot l_{e} \cdot 2.68 \cdot f_{c}^{\prime} 0.2 E_{f} \cdot t_{f} \cdot 10^{-5} \text {. }
$$

\section{Gene expression programming}

\subsection{Overview of genetic programming}

Genetic Programming was developed by Koza (1994) which is an extension to Genetic Algorithms. Gene expression programming (GEP) is a branch of Genetic programming (GP) that was developed by Ferreira (2002). GEP is superior of the old GP system with higher performance and capability of solving relatively complex problems using small population sizes (Ferreira, 2002). The GEP uses linear strings of fixed length (the genome or chromosomes) for the created computer program which are then expressed as nonlinear entities of different sizes and shapes called as expression trees (ET) (Sarıdemir, 2010; A. H. Gandomi, Alavi, Kazemi, \& M. Gandomi, 2014; Özcan, 2012; Jafari \& Mahini, 2017). Figure 1 shows an example of ET. The solution in GEP can be expressed in two languages; the language of genes and the language of ETs (tree like structure). It makes possible to infer exactly the phenotype given the sequence of a gene, and vice versa, which is termed as Karva language (Tanyildizi \& Çevik, 2010). In GEP, there are five basic components: a function set, a terminal set, a fitness function, control parameters, and a terminal condition. GEP is developed based on two main parameters, chromosomes and expression trees (ETs). The information is translated from the chromosome to the ETs. Chromosomes may contain one or more genes indicating a mathematical expression. The gene in GEP is composed of a head and a tail. The head is composed of both function and terminal symbols (constants, variables, functions, and mathematical operators) such as $(1, a, b, \sqrt{\text {, }}$ $\left.\cos ,{ }^{*},-, /\right)$ (Aval, Ketabdari, \& Gharebaghi, 2017). The tail contains only terminals (constant and variables) such as $(1, a, b, c)$. The linking between the genes can be done by a mathematical operator such as addition, subtraction, multiplication, division, etc. For example, the ETs shown in Figure 1 can be written mathematically as $(a \times 3)+(\sqrt{b})$.

There are five major steps to develop a new model using Gene expression programming. First, a fitness function is selected followed by selecting the set of terminals and the set of functions to create the chromosomes. The chromosomal architecture including the length of the head and the number of genes is selected in the third step. The linking function is selected in the fourth step. Finally, the set of genetic operators that cause variation and their rates is selected in the fifth step (Ferreira, 2002).

Several studies that conducted recently have shown that GEP can be used efficiently in civil engineering applications (Mousavi, Aminian, Gandomi, Alavi, \& Bolandi, 2012; Soleimani, Rajaei, Jiao, Sabz, \& Soheilinia, 2018; Lim, Karakus, \& Ozbakkaloglu, 2016; González-Taboada, González-Fonteboa, Martínez-Abella, \& Pérez-Ordóñez, 2016; Gholampour, Gandomi, \& Ozbakkaloglu, 2017; Gandomi et al., 2014; Nazari \& Torgal, 2013). The GEP models are developed using an experimental database and can reasonably predict the results. Mousavi et al. (2012) proposed a model for predicting compressive strength of high-performance concrete (HPC) mixes using gene expression programming. Nazari and Torgal (2013) poposed a GEP model to predict the compressive strength of geopolymeric binders. Aval et al. (2017) proposed a model for estimating shear strength of short rectangular reinforced concrete column using Gene Expression Programming. Ozcan (2012) used GEP to develop a model for splitting tensile strength of concrete. Lim et al. (2016) have proposed genetic programming (GP) models for predicting the ultimate condition of FRP-confined concrete while Mansouri, Azmathulla, and $\mathrm{Hu}$ (2018) have proposed a GEP model to predict the ultimate axial strain of fiberreinforced polymer-confined concrete. Antoniou, Geor-

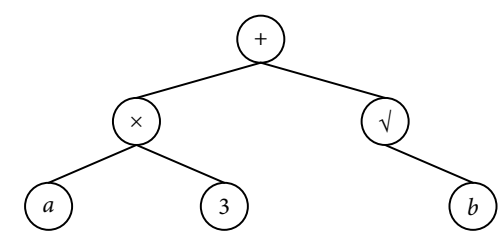

Figure 1. Example of GEP expression tree (Koza, 1994) 
gopoulos, Theofilatos, Vassilopoulos, and Likothanassis (2010) have used GEP for Fatigue modelling of composite materials. Gandomi, Alavi, Ting, and Yang (2013) have predicted the elastic modulus of concrete using GEP.

\subsection{Model development}

The GEP model proposed in the current study is developed in GeneXproTools (Gepsoft, 2014) software. Several runs have been conducted in order to develop the best model with adequate accuracy. Different GEP models are developed in this study by varying the number of genes, chromosomes, head size, and linking function in order to choose the model that best fit the experimental results. The optimal parameters of the selected GEP model are shown in Table 1 where the values are obtained from 100 different runs adopting trial and error method. The number of chromosomes determines the running time at which increasing the number of chromosomes results in increasing the running time (Gholampour et al., 2017). Furthermore, increasing the number of genes results in over fitting and the generation of a complex function (Gholampour et al., 2017). The number of genes is set to 3 in this study and the used linking functions are shown in Table 1.

The expression tree for the developed GEP model is shown in Figure 2 . In the expression tree $d_{0}, d_{1}, d_{2}, d_{3}, d_{4}$, $d_{5}, d_{6}$ and $d_{7}$ are $f_{c}^{\prime}, D, f_{f t}, t, E_{f}, f_{A t}, l_{f}$ and $b_{f}$ respectively
Table 1. GEP setting parameter

\begin{tabular}{|l|c|}
\hline \multicolumn{2}{|c|}{ GEP Model } \\
\hline Function set & $+,-,{ }^{\star}, /, \exp (x), \ln , x^{2}, 1 / x$ \\
\hline Genes & 3 \\
\hline Chromosomes & 30 \\
\hline Head size & 8 \\
\hline Linking function & multiplication \\
\hline Constant per gene & 5 \\
\hline Mutation rate & 0.05 \\
\hline Gene inversion rate & 0.1 \\
\hline Gene transposition rate & 0.1 \\
\hline One point recombination rate & 0.3 \\
\hline Two point recombination rate & 0.3 \\
\hline IS transportation rate & 0.1 \\
\hline RIS transportation rate & 0.1 \\
\hline
\end{tabular}

and $c_{0}$ to $c_{4}$ are constants. The constants of the first gene $c_{0}$, $c_{2}$ and $c_{3}$ are $-8.21,-2.45$ and -4.66 respectively and the constants of the second gene $c_{2}$ and $c_{4}$ are 5.95 and 58.74 respectively. The third gene has only one constant $c_{2}$ that equals to -2.26 . The proposed equation is extracted from the expression tree and is shown in Eqn (11). The GEP model expression is able to predict the bond strength between FRP and concrete surface with reasonable accuracy.

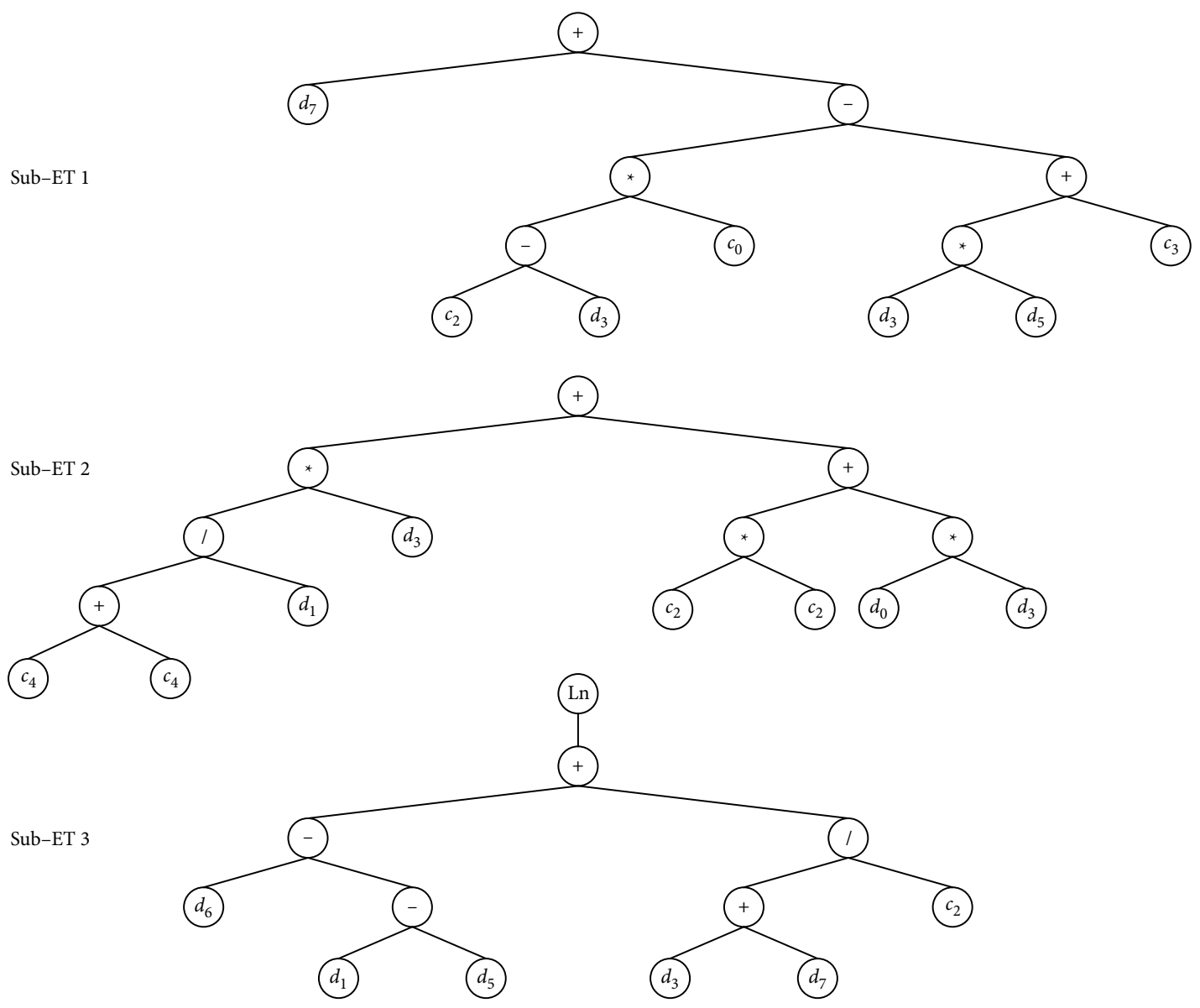

Figure 2. Expression tree of the developed GEP model 


$$
\begin{aligned}
& P=\left[b_{f}+24.79+8.21 t-t \times f_{A t}\right] \times \\
& {\left[\frac{117.49 \mathrm{t}}{D}+35.4+f_{c}^{\prime} \times t\right] \times} \\
& {\left[\ln \left(l_{f}-D+f_{A t}-0.443 \mathrm{t}-0.443 b_{f}\right] .\right.}
\end{aligned}
$$

\section{Performance measures of the GEP model}

The performance of the proposed GEP models are then statistically evaluated using the coefficient of determination R-squared $\left(\mathrm{R}^{2}\right)$, mean absolute error (MAE), and root mean square error (RMSE) that defined in Eqns (12) to (14).

$$
\begin{aligned}
& \mathrm{R}^{2}=\frac{\left(\sum_{i=1}^{N}\left(X_{i}-\bar{X}\right)\left(Y_{i}-\bar{Y}\right)\right)^{2}}{\sum_{i=1}^{N}\left(X_{i}-\bar{X}\right)^{2} \sum_{i=1}^{N}\left(Y_{i}-\bar{Y}\right)^{2}} ; \\
& \text { MAE }=\frac{1}{N} \sum_{i=1}^{N}\left|X_{i}-Y_{i}\right| ; \\
& \text { RMSE }=\sqrt{\frac{1}{N} \sum_{i=1}^{N}\left(X_{i}-Y_{i}\right)^{2} .}
\end{aligned}
$$

The statistical values of $\left(\mathrm{R}^{2}, \mathrm{MAE}, \mathrm{RMSE}\right)$ for the training, validation and all data are, $(75.3 \%, 2.7 \%, 4.7 \%)$, $(82.6 \%, 1.2 \%, 2.7 \%)$ and $(77.6 \%, 4.0 \%, 5.4 \%)$ respectively as shown in Table 2. Based on the performance evaluation results, the GEP has shown a good correlation between the predicted and measured values where the values of

Table 2. Performance of GEP model

\begin{tabular}{|l|c|c|c|}
\hline \multicolumn{1}{|c|}{ GEP1 } & $\mathrm{R}^{2}$ & MAE & RMSE \\
\hline Training & 0.75 & 2.7 & 4.7 \\
\hline Validation & 0.83 & 1.2 & 2.7 \\
\hline All data & 0.78 & 4.0 & 5.4 \\
\hline
\end{tabular}

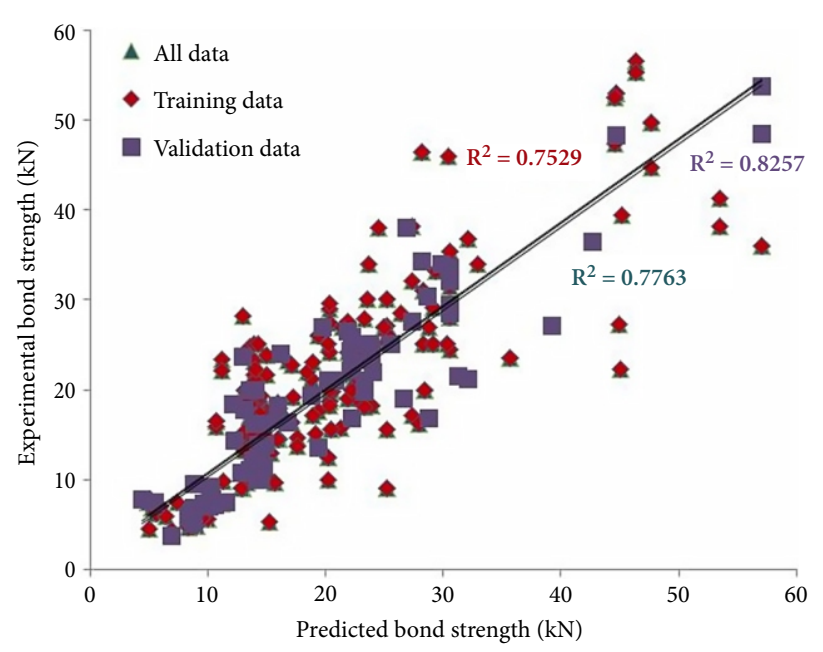

Figure 3. Comparison between the predicted and experimental values of training, validation and all data using GEP model
$\mathrm{R}^{2}$ are high and the values of MAE and RMSE (error) are low for training, validation and all data. This indicates that the GEP model has both prediction ability and generalization performance. Furthermore, a comparison is made between the predicted and experimental bond strength in Figure 3 for the testing, validation and all data respectively. The distribution of points shown in the figures is close to the ideal fit and this means that the proposed GEP model has a reasonable capability in prediction the bond strength. Table A.1 compares between the experimental bond strength and the bond strength predicted using the GEP equation for a sample of the experimental training database.

\section{GEP model sensitivity}

The proposed GEP model shows good performance and can reasonably predict the bond strength between FRP and concrete within the large experimental database. Therefore, it would be worth to further validating the proposed model by investigating whether the model has captured the sensitivity of the input parameters to the predicted bond strength. Thus, a parametric study is performed for the proposed GEP equation based on the input parameters. The influence of each input parameter on the estimated bond strength is studied by changing each single parameter (while the other input parameters are kept constant) and then studying its effect on the bond strength that predicted by the GEP model and other existing analytical models. The influence of the input parameters on the bond strength is well known and is experimentally and analytically documented. Thus, the accuracy of the proposed GEP equation can be determined by evaluating how well the predicted values agree with the expected and analytical results.

The bond strength is predicted using the proposed GEP equation (Eqn (11)) and using other analytical models available in the literature. Reference input data are implemented in these equations in order to predict the bond strength. The reference input data are considered as follows: concrete compressive strength $\left(f_{c}^{\prime}\right)=30 \mathrm{MPa}$, maximum aggregate size $(D)=12 \mathrm{~mm}$, FRP tensile strength $\left(f_{f t}\right)=1000 \mathrm{MPa}$, FRP thickness $(t)=0.1667 \mathrm{~mm}$, FRP modulus of elasticity $\left(E_{f}\right)=230 \mathrm{GPa}$, adhesive tensile strength $\left(f_{A t}\right)=30 \mathrm{MPa}$, FRP length $\left(l_{f}\right)=100 \mathrm{~mm}$ and FRP width $\left(b_{f}\right)=200 \mathrm{~mm}$. The variation of the predicted bond strength with the input parameters is tested by varying the values of one parameter while keeping the values of the other parameters unchanged as mentioned earlier. Figures 4(a) to 4(h) show the variation of the predicted bond strength with the variation of the GEP equation's input parameters including $\left(f_{c}^{\prime}\right),(D),\left(f_{f t}\right),(t),\left(E_{f}\right),\left(f_{A t}\right),\left(l_{f}\right)$ and $\left(b_{f}\right)$ respectively. This has been done in order to evaluate the sensitivity of the GEP equation with its parameters. A comparison is also made between the bond strength predicted using the GEP equation and other equations available in the literature. It is shown in Figures 4(a) to 4(h) that the bond strength, predicted using the GEP 
a)

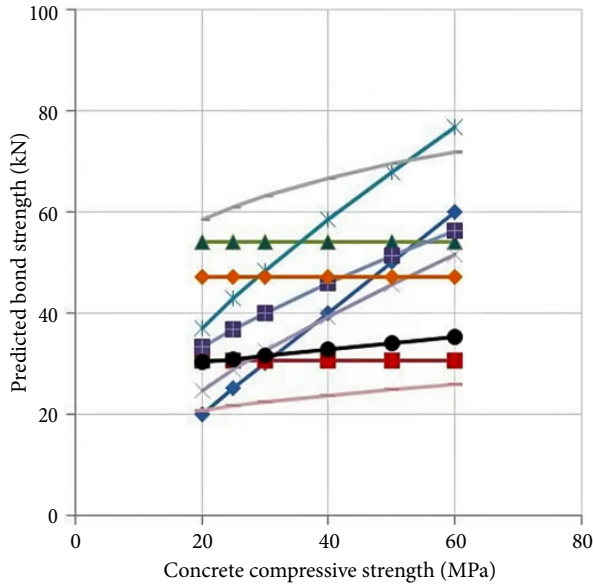

c)

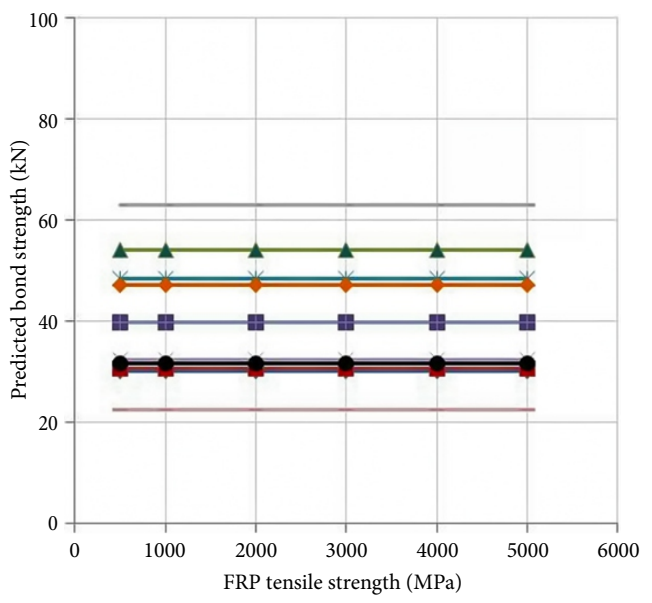

e)

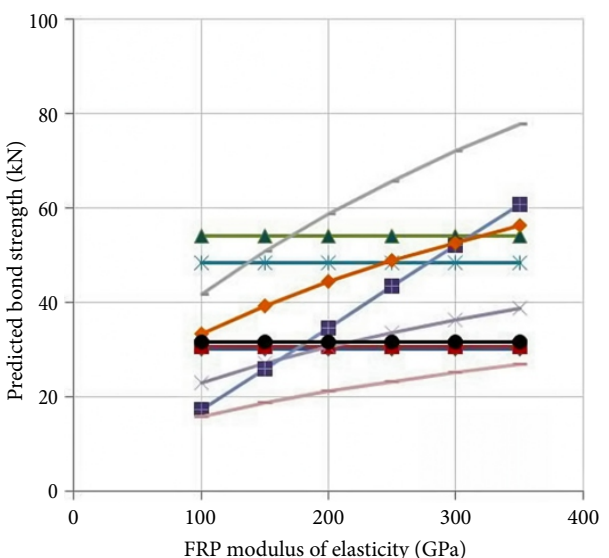

g)

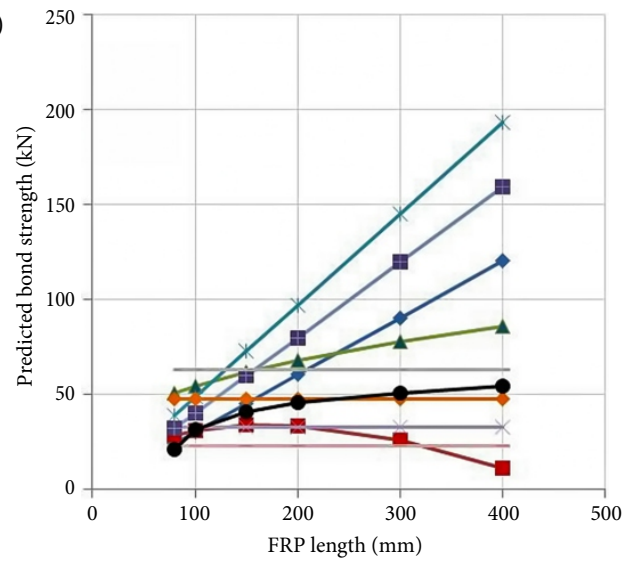

b)

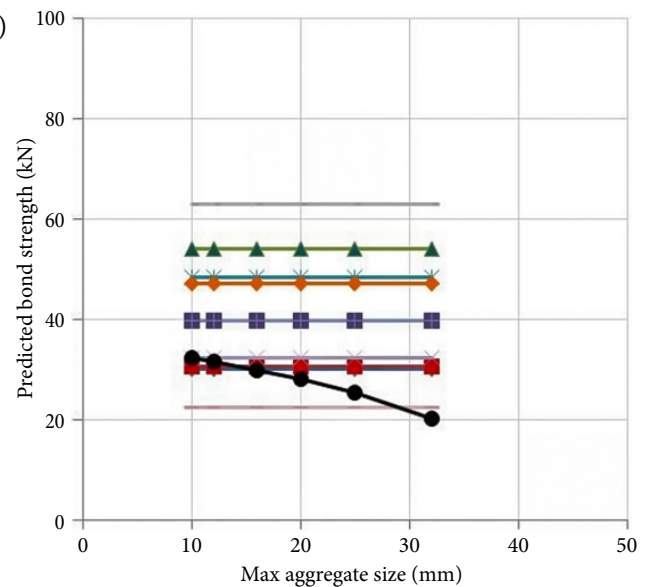

d)

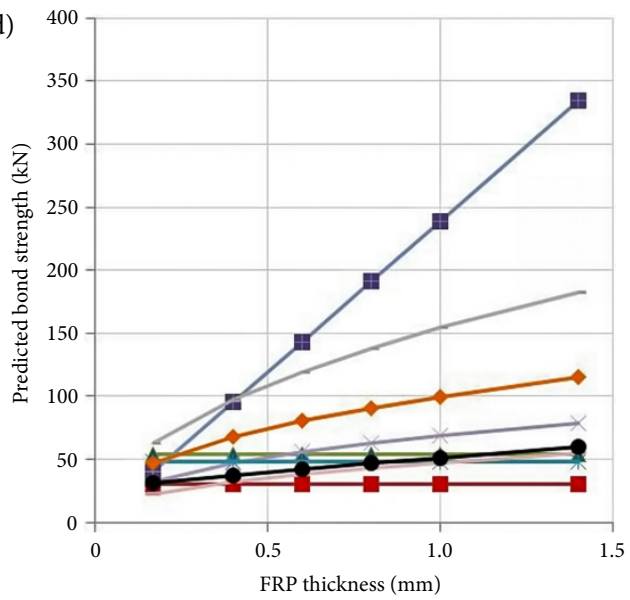

f)

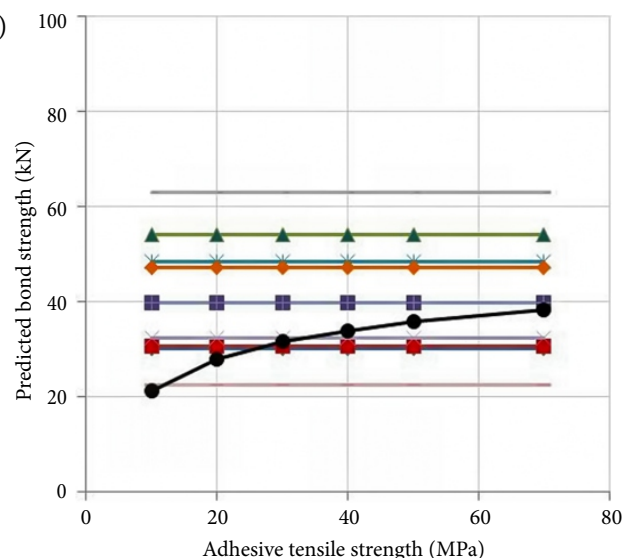

h)

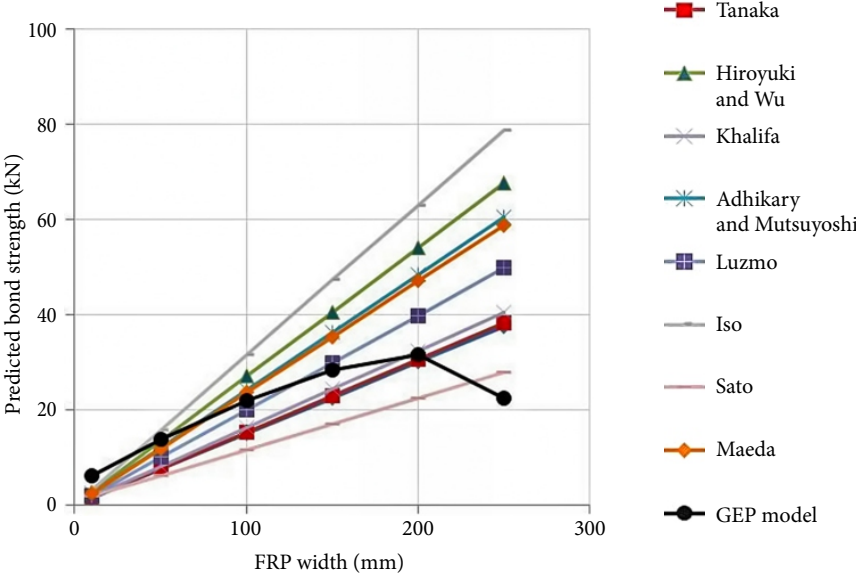

Figure 4. Effect of all input parameters on the predicted bond strength according to different models 
equation, increases by increasing the values of concrete compressive strength, FRP thickness, FRP length, adhesive tensile strength. The bond strength, predicted using the GEP equation, decreases by increasing the values of max aggregate size. FRP tensile strength and FRP modulus of elasticity dos not influence the bond strength predicted using the GEP equation. The predicted bond strength remains constant with the variation of FRP tensile strength and FRP modulus of elasticity.

The GEP model initially increases by the increase of FRP width and then decreases with higher FRP widths. The trends of the GEP model are in agreement with the overall trends of the existing models available in the literature. This indicates that the GEP model is sensitive to the input parameters and the results confirm the accuracy of the GEP model. However, the bond strength predicted using the GEP model increases by the decrease of max aggregate size and the increase of adhesive tensile strength while the bond strength remains constant by the variation of aggregate size and adhesive tensile strength for the other selected analytical models available in the literature. The selected analytical models do not account for the effect of aggregate size and adhesive tensile strength although the experimental tests available in the literature have shown that bond strength is sensitive to the aggregate size and the adhesive tensile strength. These observations confirm the consistency of the GEP model.

\section{Comparison between the bond strength predictions using the GEP model and the analytical models}

Figure 5 and Figure 6 illustrate the experimental bond strength versus the predicted bond strength calculated using the GEP model and the other analytical models mentioned earlier. The predicted bond strength using the GEP model is most fitting to the experimental results with high $\mathrm{R}^{2}$ and low MAE and RMSE compared to the other existing models as shown in Figure 5 , Figure 6, and Table 3. It is shown from the figures and Table 3 that Maeda's model (Maeda et al., 1999), which has an R squared of $34 \%$, is most fitting to the experimental results compared the other selected analytical models. The models proposed by Izumo et al. (1999) and Yang et al. (2001) have the least $\mathrm{R}^{2}$ values of $1.1 \%$ and $3.9 \%$, respectively, which are the least fitting to the experimental results. The bond

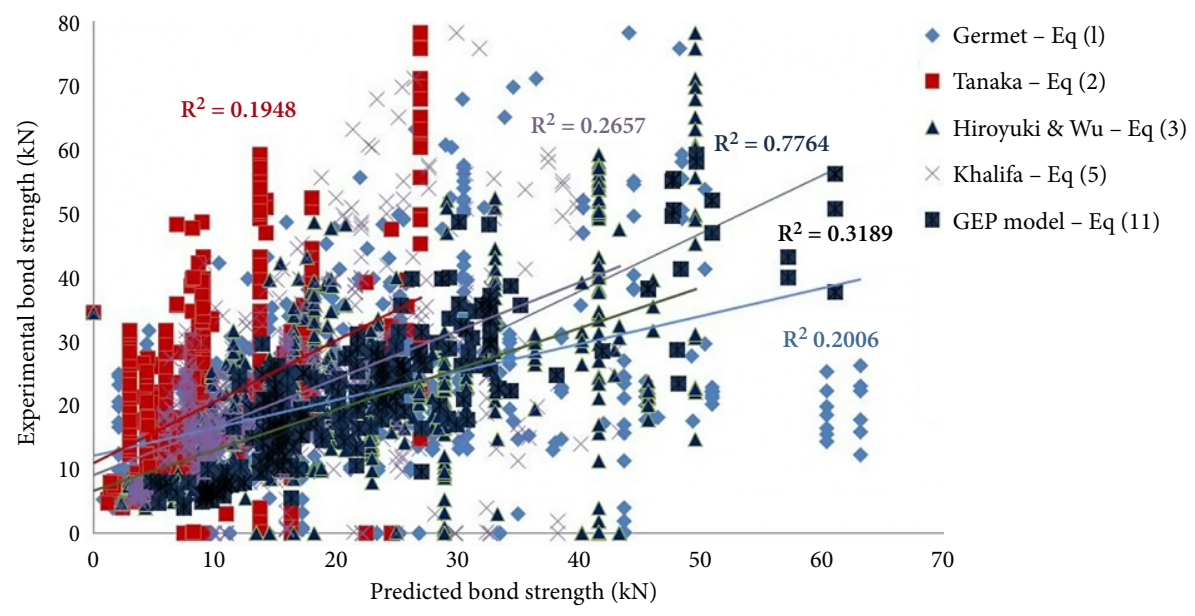

Figure 5. Comparison between the experimental and predicted bond strength using several models

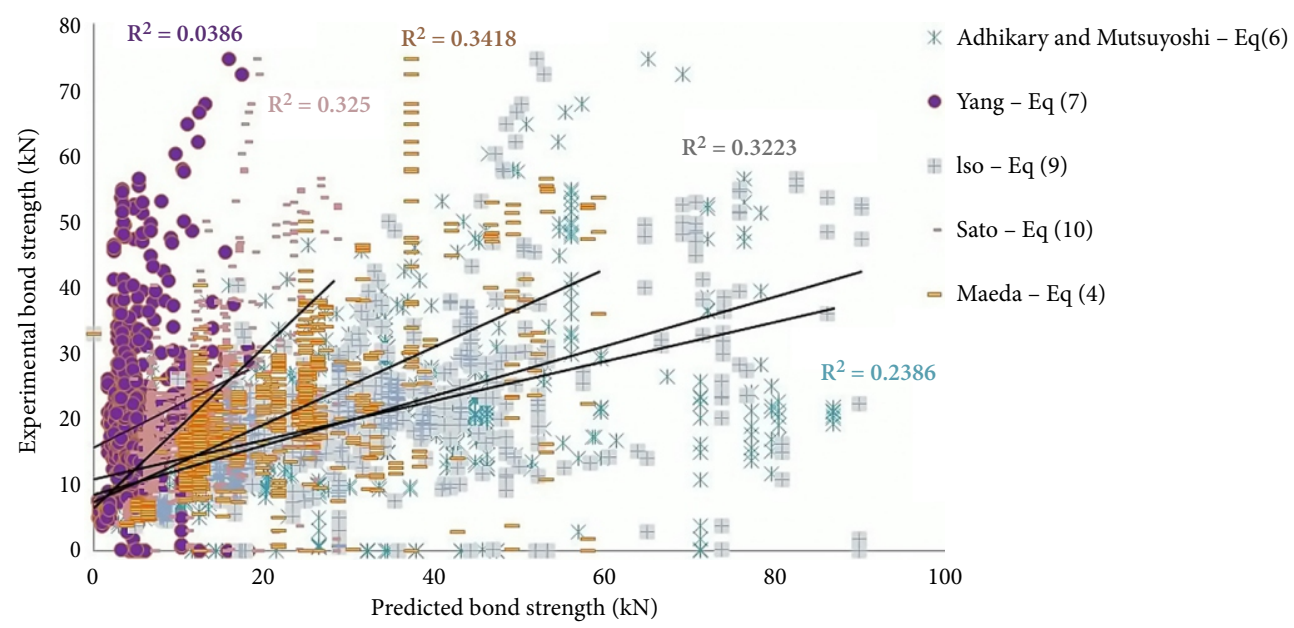

Figure 6. Comparison between the experimental and predicted bond strength using several models 
Table 3. Comparison between the GEP model and several previous models

\begin{tabular}{|l|c|c|c|}
\hline \multicolumn{1}{|c|}{ Model } & MAE (\%) & RMSE (\%) & $\mathrm{R}^{2}(\%)$ \\
\hline GEP & 4.0 & 5.4 & 78 \\
\hline Van Gemert (1980) & 8.8 & 12.4 & 19.5 \\
\hline Tanaka (1996) & 11.5 & 14.7 & 32 \\
\hline Yoshizawa and Wu (1997) & 6.6 & 9.4 & 34 \\
\hline Maeda et al. (1999) & 6.4 & 9.7 & 27 \\
\hline Khalifa et al. (1998) & 8.3 & 11.2 & 24 \\
\hline Adhikary and Mutsuyoshi (2001) & 11.5 & 17.8 & 3.9 \\
\hline Yang et al. (2001) & 24.2 & 32.9 & 1.1 \\
\hline Izumo et al. (1999) & 44.5 & 91.7 & 32 \\
\hline Iso (JCI, 2003) & 10.1 & 15.5 & 32.5 \\
\hline Sato et al. (2001) & 10.8 & 13.6 & \\
\hline
\end{tabular}

strength values predicted by Sato et al. (2001) and models by Yoshizawa and $\mathrm{Wu}(1997)$ have $\mathrm{R}^{2}$ values of $32.5 \%$ and $32 \%$ respectively which are less than that found in Maeda's et al. (1999) model but are more fitting to the experimental results than the other analytical models. The $\mathrm{R}^{2}$ of the proposed GEP model is $78 \%$ for all data. This means that the GEP model is most accurate in predicting the experimental results with the least error compared to all other selected analytical models available in the literature.

\section{Conclusions}

Gene expression programming is used in this research to develop an empirical model that predicts the bond strength between the concrete surface and CFRP sheets under direct pull out tension. The GEP model is constructed using a large and reliable database containing 770 test specimens that are collected from the literature. The model is developed using eight parameters that predominantly control the bond strength between CFRP sheets and concrete. These parameters are concrete compressive strength, maximum aggregate size, FRP tensile strength, FRP thickness, FRP modulus of elasticity, adhesive tensile strength, FRP length, and FRP width. The proposed GEP model is evaluated using a statistical assessment and a comparison is made between the bond strength values predicted using the GEP model and several analytical models available in the literature. Finally, the sensitivity of the proposed GEP model to the selected input parameters is evaluated. The following points summarize the research outcomes:

- An equation is developed to predict the bond strength between concrete and FRP using a large number of database.

- The proposed model provides an accurate prediction of the bond strength that is most fitting to the experimental database compared to the selected analytical models available in the literature. The GEP model has the lowest MAE, RMSE and the highest $\mathrm{R}^{2}$ values compared to the selected analytical models available in the literature.
- The $\mathrm{R}^{2}$ of the GEP model is $78 \%$ for all data and $83 \%$ for validation data while the highest R-squared obtained from the selected analytical models is $34 \%$.

- The bond strength, predicted using the GEP equation, increases by increasing the values of concrete compressive strength, FRP thickness, FRP length, adhesive tensile strength while it decreases by increasing the values of max aggregate.

- FRP tensile strength and FRP modulus of elasticity does not influence the bond strength predicted using the GEP equation. The predicted bond strength remains constant with the variation of FRP tensile strength and FRP modulus of elasticity.

- The trends of the GEP model are in agreement with the overall trends of the analytical models and experimental tests available in the literature. This indicates that the GEP model is sensitive to the input parameters and the results confirm the accuracy of the GEP model.

- The proposed GEP model is considered a very useful tool to evaluate the bond strength between the concrete surface and FRP for design and analysis.

\section{References}

Al-Allaf, M. H., Weekes, L., Augusthus-Nelson, L., \& Leach, P. (2016). An experimental investigation into the bond-slip behaviour between CFRP composite and lightweight concrete. Construction and Building Materials, 113, 15-27.

https://doi.org/10.1016/j.conbuildmat.2016.03.032

Al-Rousan, R., Haddad, R., \& Al-Halboni, A. (2015). Bond-slip behaviour between self-compacting concrete and carbonfibre-reinforced polymer sheets. Magazine of Concrete Research, 67(2), 89-103. https://doi.org/10.1680/macr.14.00150

Ali-Ahmad, M., Subramaniam, K., \& Ghosn, M. (2006). Experimental investigation and fracture analysis of debonding between concrete and FRP sheets. Journal of Engineering $\mathrm{Me}$ chanics, 132(9), 914-923.

https://doi.org/10.1061/(ASCE)0733-9399(2006)132:9(914)

Antoniou, M. A., Georgopoulos, E. F., Theofilatos, K. A., Vassilopoulos, A. P., \& Likothanassis, S. D. (2010). A Gene Expression Programming environment for fatigue modeling of composite materials (pp. 297-302). Berlin, Heidelberg: Springer.

https://doi.org/10.1007/978-3-642-12842-4_33 
Aval, S. B. B., Ketabdari, H., \& Gharebaghi, A. S. (2017). Estimating shear strength of short rectangular reinforced concrete columns using nonlinear regression and Gene Expression Programming. Structures, 12, 13-23.

https://doi.org/10.1016/j.istruc.2017.07.002

Adhikary, B. B., \& Mutsuyoshi, H. (2001). Study on the bond between concrete and externally bonded CFRP sheet. In FRPRCS-5: Fibre-reinforced plastics for reinforced concrete structures, 1. https://doi.org/10.1680/frprcsv1.30299

Biolzi, L., Ghittoni, C., Fedele, R., \& Rosati, G. (2013). Experimental and theoretical issues in FRP-concrete bonding. Construction and Building Materials, 41, 182-190. https://doi.org/10.1016/j.conbuildmat.2012.11.082

Cevik, A., \& Sonebi, M. (2008). Modelling the performance of self-compacting SIFCON of cement slurries using genetic programming technique. Computers and Concrete, 5(5), 475490. https://doi.org/10.12989/cac.2008.5.5.475

Czaderski, C., Soudki, K., \& Motavalli, M. (2010). Front and side view image correlation measurements on FRP to concrete pull-off bond tests. Journal of Composites for Construction, 14(4), 451-463.

https://doi.org/10.1061/(ASCE)CC.1943-5614.0000106

Ferreira, C. (2002). Gene Expression Programming in problem solving. In Soft Computing and Industry (pp. 635-653). London: Springer. https://doi.org/10.1007/978-1-4471-0123-9_54

Gandomi, A. H., Alavi, A. H., Kazemi, S., \& Gandomi, M. (2014). Formulation of shear strength of slender RC beams using gene expression programming, part I: Without shear reinforcement. Automation in Construction, 42, 112-121. https://doi.org/10.1016/j.autcon.2014.02.007

Gandomi, A. H., Alavi, A. H., Ting, T. O., \& Yang, X.-S. (2013). Intelligent modeling and prediction of elastic modulus of concrete strength via Gene Expression Programming (pp. 564-571). Berlin, Heidelberg: Springer. https://doi.org/10.1007/978-3-642-38703-6_66

Gepsoft. (2014). GeneXproTools. Data modeling \&amp; Analysis software. Retrieved from: https://www.gepsoft.com/

Gholampour, A., Gandomi, A. H., \& Ozbakkaloglu, T. (2017). New formulations for mechanical properties of recycled aggregate concrete using gene expression programming. Construction and Building Materials, 130, 122-145. https://doi.org/10.1016/j.conbuildmat.2016.10.114

Ghorbani, M., Mostofinejad, D., \& Hosseini, A. (2017). Experimental investigation into bond behavior of FRP-to-concrete under mixed-mode I/II loading. Construction and Building Materials, 132, 303-312. https://doi.org/10.1016/j.conbuildmat.2016.11.057

González-Taboada, I., González-Fonteboa, B., Martínez-Abella, F., \& Pérez-Ordóñez, J. L. (2016). Prediction of the mechanical properties of structural recycled concrete using multivariable regression and genetic programming. Construction and Building Materials, 106, 480-499.

https://doi.org/10.1016/j.conbuildmaT.2015.12.136

Haddad, R., Al-Rousan, R., \& Almasry, A. (2013). Bond-slip behavior between carbon fiber reinforced polymer sheets and heat-damaged concrete. Composites Part B: Engineering, 45(1), 1049-1060. https://doi.org/10.1016/j.compositesb.2012.09.010

Haddad, R., Al-Rousan, R., Ghanma, L., \& Nimri, Z. (2015). Modifying CFRP-concrete bond characteristics from pullout testing. Magazine of Concrete Research, 67(13), 707-717. https://doi.org/10.1680/macr.14.00271

Haddad, R. H., \& Al Dalou, A. A. (2018). Experimental study on bond behavior between corrosion-cracked reinforced concrete and CFRP sheets. Journal of Adhesion Science and Technology, 32(6), 590-608.

https://doi.org/10.1080/01694243.2017.1371912

Hadigheh, S. A., Gravina, R. J., \& Setunge, S. (2015). Identification of the interfacial fracture mechanism in the FRP laminated substrates using a modified single lap shear test set-up. Engineering Fracture Mechanics, 134, 317-329.

https://doi.org/10.1016/j.engfracmech.2014.12.001

Hosseini, A., \& Mostofinejad, D. (2013). Experimental investigation into bond behavior of CFRP sheets attached to concrete using EBR and EBROG techniques. Composites Part B: Engineering, 51, 130-139.

https://doi.org/10.1016/j.compositesb.2013.03.003

Hosseini, A., \& Mostofinejad, D. (2014). Effective bond length of FRP-to-concrete adhesively-bonded joints: Experimental evaluation of existing models. International Journal of Adhesion and Adhesives, 48, 150-158.

https://doi.org/10.1016/j.ijadhadh.2013.09.022

Iqbal, S., Ullah, N., \& Ali, A. (2018). Engineering, technology \&amp; applied science research. In Engineering, Technology \& Applied Science Research, 8. ETASR. Retrieved from https:// www.etasr.com/index.php/ETASR/article/view/1989

Irshidat, M. R., \& Al-Saleh, M. H. (2016). Effect of using carbon nanotube modified epoxy on bond-slip behavior between concrete and FRP sheets. Construction and Building Materials, 105, 511-518.

https://doi.org/10.1016/j.conbuildmat.2015.12.183

Izumo, K., Saeki, N., Fukao, M., and Horiguchi, T. 1999. Bond behavior and strength between fiber sheets and concrete. Transactions of the Japan Concrete Institute, 21, 423-430.

Jafari, S., \& Mahini, S. S. (2017). Lightweight concrete design using gene expression programing. Construction and Building Materials, 139, 93-100.

https://doi.org/10.1016/j.conbuildmat.2017.01.120

Japan Concrete Institute (JCI). (2003). Technical report of technical committee on retrofit technology.

Khalifa, A., Gold, W. J., Nanni, A., \& M.I., A. A. (1998). Contribution of externally bonded FRP to shear capacity of RC flexural members. Journal of Composites for Construction, 2(4), 195202. https://doi.org/10.1061/(ASCE)1090-0268(1998)2:4(195)

Ko, H., Matthys, S., Palmieri, A., \& Sato, Y. (2014). Development of a simplified bond stress-slip model for bonded FRPconcrete interfaces. Construction and Building Materials, 68, 142-157. https://doi.org/10.1016/j.conbuildmat.2014.06.037

Koza, J. (1994). Genetic programming as a means for programming computers by natural selection. Statistics and Computing, 4(2), 87-112. https://doi.org/10.1007/BF00175355

Lim, J. C., Karakus, M., \& Ozbakkaloglu, T. (2016). Evaluation of ultimate conditions of FRP-confined concrete columns using genetic programming. Computers \& Structures, 162, 28-37. https://doi.org/10.1016/j.compstruc.2015.09.005

Lu, X. Z., Teng, J. G., Ye, L. P., \& Jiang, J. J. (2005). Bond-slip models for FRP sheets/plates bonded to concrete. Engineering Structures, 27(6), 920-937.

https://doi.org/10.1016/j.engstruct.2005.01.014

Mansouri, I., Azmathulla, H. M., \& Hu, W. J. (2018). Gene expression programming application for prediction of ultimate axial strain of FRP-confined concrete. Elektronički Časopis Građevinskog Fakulteta Osijek, 9(16), 64-76.

https://doi.org/10.13167/2018.16.6

Maeda, T., Asano, Y., Sato, Y., Ueda, T., \& Kakuta, Y. (1999). A study on bond mechanism of carbon fiber sheet. In Proceedings of the Third International Symposium on Non-Metallic 
(FRP) Reinforcement for Concrete Structures (pp. 279-286). Japan: Japan Concrete Institute.

Mazzotti, C., Ferracuti, B., \& Bilotta, A. (2012). Sensitivity of FRP-concrete bond behavior to modification of the experimental set-up. In VI International Conference of FRP Composites in Civil Engineering.

Ming, Z., \& Ansari, F. (2004). Bond properties of FRP fabrics and concerete joints. In 13th World Conference on Earthquake Engineering. Vancouver, B.C., Canada.

Mostofinejad, D., Mofrad, M. H., Hosseini, A., \& Mofrad, H. H. (2018). Investigating the effects of concrete compressive strength, CFRP thickness and groove depth on CFRP-concrete bond strength of EBROG joints. Construction and Building Materials, 189, 323-337.

https://doi.org/10.1016/j.conbuildmat.2018.08.203

Mousavi, S. M., Aminian, P., Gandomi, A. H., Alavi, A. H., \& Bolandi, H. (2012). A new predictive model for compressive strength of HPC using gene expression programming. Advances in Engineering Software, 45(1), 105-114.

https://doi.org/10.1016/j.advengsoft.2011.09.014

Murad, Y. (2018a). The influence of CFRP orientation angle on the shear strength of RC beams. The Open Construction \& Building Technology Journal, 12. https://doi.org/10.2174/1874836801812010269

Murad, Y. (2018b). An experimental study on flexural strengthening of RC beams using CFRP sheets. International Journal of Engineering and Technology (UAE), 7, 2075-2080. https://doi.org/10.14419/ijet.v7i4.16546

Nazari, A., \& Torgal, P. F. (2013). Modeling the compressive strength of geopolymeric binders by gene expression programming-GEP. Expert Systems with Applications, 40(14), 5427-5438. https://doi.org/10.1016/j.eswa.2013.04.014

Nigro, E., Di Ludovico, M., \& Bilotta, A. (2011). Experimental investigation of FRP-concrete debonding under cyclic actions. Journal of Materials in Civil Engineering, 23(4), 360371. https://doi.org/10.1061/(ASCE)MT.1943-5533.0000173

Ozbakkaloglu, T., Fang, C., \& Gholampour, A. (2017). Influence of FRP anchor configuration on the behavior of FRP plates externally bonded on concrete members. Engineering Structures, 133, 133-150. https://doi.org/10.1016/j.engstruct.2016.12.005

Ozbakkaloglu, T., \& Saatcioglu, M. (2009). Tensile behavior of FRP anchors in concrete. Journal of Composites for Construction, 13(2), 82-92.

https://doi.org/10.1061/(ASCE)1090-0268(2009)13:2(82)

Özcan, F. (2012). Gene expression programming based formulations for splitting tensile strength of concrete. Construction and Building Materials, 26(1), 404-410.

https://doi.org/10.1016/j.conbuildmat.2011.06.039

Pan, J., \& Leung, C. K. (2007). Effect of concrete composition on FRP/concrete bond capacity. Journal of Composites for Construction, 11(6), 611-618.

https://doi.org/10.1061/(ASCE)1090-0268(2007)11:6(611)

Sarıdemir, M. (2010). Genetic programming approach for prediction of compressive strength of concretes containing rice husk ash. Construction and Building Materials, 24(10), 19111919. https://doi.org/10.1016/j.conbuildmat.2010.04.011

Sato, Y., Asano, Y., \& Ueda, T. 2001. Fundamental study on bond mechanism of carbon fiber sheet. J-STAGE, 37, 97-115.

Serbescu, A., Guadagnini, M., \& Pilakoutas, K. (2013). Standardised double-shear test for determining bond of FRP to concrete and corresponding model development. Composites Part B: Engineering, 55, 277-297.

https://doi.org/10.1016/j.compositesb.2013.06.019

Sharma, S. K., Mohamed Ali, M. S., Goldar, D., \& Sikdar, P. K. (2006). Plate-concrete interfacial bond strength of FRP and metallic plated concrete specimens. Composites Part B: Engineering, 37(1), 54-63.

https://doi.org/10.1016/j.compositesb.2005.05.011

Soleimani, S., Rajaei, S., Jiao, P., Sabz, A., \& Soheilinia, S. (2018). New prediction models for unconfined compressive strength of geopolymer stabilized soil using multi-gen genetic programming. Measurement, 113, 99-107.

https://doi.org/10.1016/j.measurement.2017.08.043

Sonebi, M., \& Cevik, A. (2009). Genetic programming based formulation for fresh and hardened properties of self-compacting concrete containing pulverised fuel ash. Construction and Building Materials, 23(7), 2614-2622.

https://doi.org/10.1016/j.conbuildmat.2009.02.012

Tanaka, T. (1996). Shear resisting mechanism of reinforced concrete beams with CFS as shear reinforcement. Hokkaido University.

Tanyildizi, H., \& Çevik, A. (2010). Modeling mechanical performance of lightweight concrete containing silica fume exposed to high temperature using genetic programming. Construction and Building Materials, 24(12), 2612-2618. https://doi.org/10.1016/j.conbuildmat.2010.05.001

Toutanji, H., \& Ortiz, G. (2001). The effect of surface preparation on the bond interface between FRP sheets and concrete members. Composite Structures, 4, 457-462.

https://doi.org/10.1016/S0263-8223(01)00057-5

Toutanji, H., Saxena, P., Zhao, L., \& Ooi, T. (2007). Prediction of interfacial bond failure of FRP-concrete surface. Journal of Composites for Construction, 11(4), 427-436. https://doi.org/10.1061/(ASCE)1090-0268(2007)11:4(427)

Van Gemert, D. (1980). Force transfer in epoxy bonded steel/concrete joints. International Journal of Adhesion and Adhesives, 1(2), 67-72. https://doi.org/10.1016/0143-7496(80)90060-3

Wan, B., Jiang, C., \& Wu, Y.-F. (2018). Effect of defects in externally bonded FRP reinforced concrete. Construction and Building Materials, 172, 63-76. https://doi.org/10.1016/j.conbuildmat.2018.03.217

Woo, S.-K., \& Lee, Y. (2010). Experimental study on interfacial behavior of CFRP-bonded concrete. KSCE Journal of Civil Engineering, 14(3), 385-393. https://doi.org/10.1007/s12205-010-0385-0

Wu, Y.-F., \& Jiang, C. (2013). Quantification of bond-slip relationship for externally bonded FRP-to-concrete joints. Journal of Composites for Construction, 17(5), 673-686. https://doi.org/10.1061/(ASCE)CC.1943-5614.0000375

Yang, Y. X., Yue, Q. R. \& Hu, Y. C. (2001). Experimental study on bond performance between carbon fiber sheets and concrete. Journal of Building Structures, 22.

Yao, J., Teng, J. G., \& Chen, J. F. (2005). Experimental study on FRP-to-concrete bonded joints. Composites Part B: Engineering, 36(2), 99-113.

https://doi.org/10.1016/j.compositesb.2004.06.001

Yoshizawa, H., \& Wu, Z. (1997). Analysis of debonding fracture properties of CFS strengthened RC member subject to tension. In Proceedings of the $3^{\text {rd }}$ International Symposium on Non-Metallic (FRP) Reinforcement for Concrete Structures (pp. 287-294). 


\section{Abbreviations}

FRP - fiber reinforced polymer;

CFRP - carbon fiber reinforced polymer;

GEP - Gene Expression Programming;

ANN - Artificial Neural Network;

$f_{c}^{\prime}$ - concrete compressive strength;
$D$ - maximum aggregate size;

$f_{f t}-$ FRP tensile strength;

$t$ - RP thickness;

$E_{f}$ - FRP modulus of elasticity;

$f_{A t}$ - Adhesive tensile strength;

$l_{f}$ - FRP length;

$b_{f}$ - FRP width.

\section{APPENDIX}

Table A.1. Sample of the experimental training database vs the predicted bond strength using GEP equation

\begin{tabular}{|c|c|c|c|c|c|c|c|c|c|c|c|}
\hline Authors & $\begin{array}{c}\text { Specimen } \\
\text { name }\end{array}$ & $\begin{array}{l}\text { Concrete } \\
\text { comp. } \\
\text { strength } \\
(\mathrm{MPa})\end{array}$ & $\begin{array}{c}\text { Max } \\
\text { aggregate } \\
\text { size }(\mathrm{mm})\end{array}$ & $\begin{array}{c}\text { FRP } \\
\text { tensile } \\
\text { strength } \\
(\mathrm{MPa})\end{array}$ & $\begin{array}{c}\text { FRP } \\
\text { thickness } \\
(\mathrm{mm})\end{array}$ & $\begin{array}{c}\text { FRP } \\
\text { modulus } \\
\text { of } \\
\text { elasticity } \\
(\mathrm{GPa})\end{array}$ & $\begin{array}{c}\text { Adhesive } \\
\text { tensile } \\
\text { strength } \\
(\mathrm{MPa})\end{array}$ & $\begin{array}{c}\text { FRP } \\
\text { length } \\
(\mathrm{mm})\end{array}$ & $\begin{array}{c}\text { FRP } \\
\text { width } \\
(\mathrm{mm})\end{array}$ & $\begin{array}{l}\text { Exp. } \\
\text { bond } \\
\text { strength } \\
(\mathrm{kN})\end{array}$ & $\begin{array}{l}\text { Predicted } \\
\text { bond } \\
\text { strength } \\
(\mathrm{kN})\end{array}$ \\
\hline \multirow{6}{*}{$\begin{array}{l}\text { Czaderski } \\
\text { et al. (2010) }\end{array}$} & S512 & 38 & 32 & 2800 & 1.2 & 165 & 24.8 & 250 & 50 & 24.8 & 25.28 \\
\hline & S512 & 38 & 32 & 2800 & 1.2 & 165 & 24.8 & 250 & 50 & 21 & 25.28 \\
\hline & M514 & 38 & 32 & 2400 & 1.4 & 210 & 24.8 & 250 & 50 & 28.7 & 26.07 \\
\hline & M514 & 38 & 32 & 2400 & 1.4 & 210 & 24.8 & 250 & 50 & 19.9 & 26.07 \\
\hline & S624 & 38 & 32 & 2800 & 2.4 & 165 & 24.8 & 250 & 60 & 32.1 & 32.71 \\
\hline & S624 & 38 & 32 & 2800 & 2.4 & 165 & 24.8 & 250 & 60 & 31.1 & 32.71 \\
\hline \multirow{2}{*}{$\begin{array}{l}\text { Biolzi } \\
\text { et al. (2013) }\end{array}$} & $1 \mathrm{~L}$ & 32.59 & 25 & 3100 & 1.4 & 170 & 24.8 & 30 & 50 & 9.53 & 8.81 \\
\hline & $2 \mathrm{~L}$ & 32.59 & 25 & 3100 & 1.4 & 170 & 24.8 & 50 & 50 & 17.1 & 14.89 \\
\hline \multirow{7}{*}{$\begin{array}{l}\text { Pan and } \\
\text { Leung (2007) }\end{array}$} & M1 & 43.1 & 20 & 4200 & 0.11 & 235 & 30 & 300 & 50 & 16.8 & 16.71 \\
\hline & M2 & 35.2 & 20 & 4200 & 0.11 & 235 & 30 & 300 & 50 & 16.5 & 16.35 \\
\hline & M3 & 57.5 & 20 & 4200 & 0.11 & 235 & 30 & 300 & 50 & 17.3 & 17.36 \\
\hline & M4 & 38.6 & 20 & 4200 & 0.11 & 235 & 30 & 300 & 50 & 16.5 & 16.51 \\
\hline & M5 & 61.5 & 20 & 4200 & 0.11 & 235 & 30 & 300 & 50 & 16.8 & 17.54 \\
\hline & M9 & 52.4 & 20 & 4200 & 0.11 & 235 & 30 & 300 & 50 & 16.3 & 17.13 \\
\hline & M10 & 57.9 & 20 & 4200 & 0.11 & 235 & 30 & 300 & 50 & 17.2 & 17.38 \\
\hline \multirow{3}{*}{$\begin{array}{l}\text { Ali-Ahmad } \\
\text { et al. (2006) }\end{array}$} & 1 & 38 & 10 & 3820 & 0.167 & 230 & 29.4 & 150 & 46 & 11.5 & 14.70 \\
\hline & 4 & 38 & 10 & 3820 & 0.167 & 230 & 29.4 & 150 & 46 & 12.8 & 14.70 \\
\hline & 5 & 38 & 10 & 3820 & 0.167 & 230 & 29.4 & 150 & 46 & 13.2 & 14.70 \\
\hline \multirow{4}{*}{$\begin{array}{l}\text { Hosseini } \\
\text { and } \\
\text { Mostofinejad } \\
(2013)\end{array}$} & EBR-20-1 & 36.8 & 10 & 4300 & 0.131 & 238 & 30 & 20 & 48 & 7.94 & 8.55 \\
\hline & EBR-20-2 & 36.8 & 10 & 4300 & 0.131 & 238 & 30 & 20 & 48 & 7.58 & 8.55 \\
\hline & EBR-35-1 & 36.8 & 10 & 4300 & 0.131 & 238 & 30 & 35 & 48 & 9.24 & 10.27 \\
\hline & EBR-35-2 & 36.8 & 10 & 4300 & 0.131 & 238 & 30 & 35 & 48 & 9.88 & 10.27 \\
\hline \multirow{14}{*}{$\begin{array}{l}\text { Al-Allaf } \\
\text { et al. (2016) }\end{array}$} & BL1-1a & 32 & 14 & 4000 & 0.1178 & 240 & 19 & 100 & 100 & 19.34 & 20.35 \\
\hline & BL1-1b & 32 & 14 & 4000 & 0.1178 & 240 & 19 & 100 & 100 & 18.71 & 20.35 \\
\hline & BL1-1c & 32 & 14 & 4000 & 0.1178 & 240 & 19 & 100 & 100 & 19.99 & 20.35 \\
\hline & BL1-1d & 32 & 14 & 4000 & 0.1178 & 240 & 19 & 150 & 100 & 19.86 & 23.33 \\
\hline & BL1-2a & 32 & 14 & 4000 & 0.1178 & 240 & 19 & 150 & 100 & 27.31 & 23.33 \\
\hline & BL1-2b & 32 & 14 & 4000 & 0.1178 & 240 & 19 & 150 & 100 & 23.8 & 23.33 \\
\hline & BL1-2c & 32 & 14 & 4000 & 0.1178 & 240 & 19 & 150 & 100 & 27.8 & 23.33 \\
\hline & BL1-2d & 32 & 14 & 4000 & 0.1178 & 240 & 19 & 200 & 100 & 25.22 & 25.18 \\
\hline & BL1-3a & 32 & 14 & 4000 & 0.1178 & 240 & 19 & 200 & 100 & 26.15 & 25.18 \\
\hline & BL1-3b & 32 & 14 & 4000 & 0.1178 & 240 & 19 & 200 & 100 & 27.11 & 25.18 \\
\hline & BL2-1d & 32 & 14 & 4000 & 0.1178 & 240 & 19 & 100 & 100 & 8.24 & 20.35 \\
\hline & BL2-2a & 32 & 14 & 4000 & 0.1178 & 240 & 19 & 100 & 100 & 9.91 & 20.35 \\
\hline & BL3-1a & 32 & 14 & 4000 & 0.1178 & 240 & 19 & 100 & 100 & 22.99 & 20.35 \\
\hline & BL3-1b & 32 & 14 & 4000 & 0.1178 & 240 & 19 & 100 & 100 & 18.19 & 20.35 \\
\hline
\end{tabular}


End of Table A.1

\begin{tabular}{|c|c|c|c|c|c|c|c|c|c|c|c|}
\hline Authors & $\begin{array}{l}\text { Specimen } \\
\text { name }\end{array}$ & $\begin{array}{l}\text { Concrete } \\
\text { comp. } \\
\text { strength } \\
(\mathrm{MPa})\end{array}$ & $\begin{array}{c}\text { Max } \\
\text { aggregate } \\
\text { size }(\mathrm{mm})\end{array}$ & $\begin{array}{c}\text { FRP } \\
\text { tensile } \\
\text { strength } \\
(\mathrm{MPa})\end{array}$ & $\begin{array}{l}\text { FRP } \\
\text { thickness } \\
(\mathrm{mm})\end{array}$ & $\begin{array}{c}\text { FRP } \\
\text { modulus } \\
\text { of } \\
\text { elasticity } \\
(\mathrm{GPa})\end{array}$ & $\begin{array}{l}\text { Adhesive } \\
\text { tensile } \\
\text { strength } \\
(\mathrm{MPa})\end{array}$ & $\begin{array}{c}\text { FRP } \\
\text { length } \\
(\mathrm{mm})\end{array}$ & $\begin{array}{c}\text { FRP } \\
\text { width } \\
(\mathrm{mm})\end{array}$ & $\begin{array}{c}\text { Exp. } \\
\text { bond } \\
\text { strength } \\
(\mathrm{kN})\end{array}$ & $\begin{array}{l}\text { Predicted } \\
\text { bond } \\
\text { strength } \\
(\mathrm{kN})\end{array}$ \\
\hline \multirow{10}{*}{$\begin{array}{l}\text { Al-Allaf } \\
\text { et al. (2016) }\end{array}$} & BL3-1c & 32 & 14 & 4000 & 0.1178 & 240 & 19 & 100 & 100 & 18.69 & 20.35 \\
\hline & BL3-2a & 32 & 14 & 4000 & 0.1178 & 240 & 19 & 100 & 100 & 19.54 & 20.35 \\
\hline & BN1-1a & 32 & 14 & 4000 & 0.1178 & 240 & 19 & 150 & 100 & 22.1 & 23.33 \\
\hline & BN1-1b & 32 & 14 & 4000 & 0.1178 & 240 & 19 & 100 & 100 & 21.9 & 20.35 \\
\hline & BN3-2a & 32 & 14 & 4000 & 0.1178 & 240 & 19 & 100 & 100 & 22.44 & 20.35 \\
\hline & BN3-2b & 32 & 14 & 4000 & 0.1178 & 240 & 19 & 150 & 100 & 23.09 & 23.33 \\
\hline & BN4-1a & 32 & 14 & 4000 & 0.1178 & 240 & 19 & 150 & 50 & 14.8 & 14.42 \\
\hline & BN4-1b & 32 & 14 & 4000 & 0.1178 & 240 & 19 & 150 & 50 & 15.55 & 14.42 \\
\hline & BN4-2a & 32 & 14 & 4000 & 0.1178 & 240 & 19 & 150 & 150 & 29.05 & 31.22 \\
\hline & BN4-2b & 32 & 14 & 4000 & 0.1178 & 240 & 19 & 150 & 150 & 29.69 & 31.22 \\
\hline \multirow{12}{*}{$\begin{array}{l}\text { Hadigheh } \\
\text { et al. (2015) }\end{array}$} & P7.1 & 47.1 & 14 & 3170 & 1.4 & 165 & 24.8 & 200 & 50 & 32 & 30.53 \\
\hline & P7.2 & 47.1 & 14 & 3170 & 1.4 & 165 & 24.8 & 200 & 50 & 28.9 & 30.53 \\
\hline & P7.3 & 47.1 & 14 & 3170 & 1.4 & 165 & 24.8 & 200 & 50 & 28.5 & 30.53 \\
\hline & P8.1 & 47.1 & 14 & 3170 & 1.4 & 165 & 24.8 & 200 & 50 & 28.1 & 30.53 \\
\hline & P8.2 & 47.1 & 14 & 3170 & 1.4 & 165 & 24.8 & 200 & 50 & 31.4 & 30.53 \\
\hline & P8.3 & 47.1 & 14 & 3170 & 1.4 & 165 & 24.8 & 200 & 50 & 33.5 & 30.53 \\
\hline & P10.1 & 47.1 & 14 & 3170 & 1.4 & 165 & 24.8 & 200 & 25 & 17.3 & 15.90 \\
\hline & $\mathrm{P} 10.2$ & 47.1 & 14 & 3170 & 1.4 & 165 & 24.8 & 200 & 25 & 16 & 15.90 \\
\hline & P10.3 & 47.1 & 14 & 3170 & 1.4 & 165 & 24.8 & 200 & 25 & 16 & 15.90 \\
\hline & P11.1 & 47.1 & 14 & 3170 & 1.4 & 165 & 24.8 & 200 & 50 & 29.2 & 30.53 \\
\hline & P11.1 & 47.1 & 14 & 3170 & 1.4 & 165 & 24.8 & 200 & 50 & 29.5 & 30.53 \\
\hline & P12.3 & 47.1 & 14 & 3170 & 1.4 & 165 & 24.8 & 200 & 80 & 48.5 & 47.62 \\
\hline \multirow{8}{*}{$\begin{array}{l}\text { Mostofinejad } \\
\text { et al. (2018) }\end{array}$} & $\begin{array}{c}\text { EBR } \\
20-13-1\end{array}$ & 20 & 20 & 4300 & 0.13 & 238 & 30 & 150 & 48 & 10.82 & 13.37 \\
\hline & $\begin{array}{c}\text { EBR } \\
20-26-1\end{array}$ & 20 & 20 & 3900 & 0.26 & 230 & 30 & 150 & 48 & 13.97 & 13.94 \\
\hline & $\begin{array}{c}\text { EBR } \\
32-26-1\end{array}$ & 32 & 20 & 3900 & 0.26 & 230 & 30 & 150 & 48 & 14.42 & 14.97 \\
\hline & $\begin{array}{c}\text { EBR } \\
32-26-2\end{array}$ & 32 & 20 & 3900 & 0.26 & 230 & 30 & 150 & 48 & 14.45 & 14.97 \\
\hline & $\begin{array}{c}\text { EBR } \\
43-26-1\end{array}$ & 43 & 20 & 3900 & 0.26 & 230 & 30 & 150 & 48 & 14.5 & 15.92 \\
\hline & $\begin{array}{c}\text { EBR } \\
43-26-2\end{array}$ & 43 & 20 & 3900 & 0.26 & 230 & 30 & 150 & 48 & 15.63 & 15.92 \\
\hline & $\begin{array}{c}\mathrm{GM} \\
20-26-2-2\end{array}$ & 20 & 20 & 3900 & 0.26 & 230 & 30 & 150 & 48 & 14.91 & 13.94 \\
\hline & $\begin{array}{c}\mathrm{GM} \\
32-13-2-1\end{array}$ & 32 & 20 & 4300 & 0.13 & 238 & 30 & 150 & 48 & 12.78 & 13.90 \\
\hline \multirow{6}{*}{$\begin{array}{l}\text { Ghorbani } \\
\text { et al. (2017) }\end{array}$} & $\begin{array}{c}\text { EBR } \\
100-0-1\end{array}$ & 34 & 12.5 & 3900 & 0.166 & 230 & 30 & 100 & 50 & 12.16 & 13.80 \\
\hline & \begin{tabular}{|c|} 
EBR \\
$100-\mathrm{N} 2.3-2$ \\
\end{tabular} & 34 & 12.5 & 3900 & 0.166 & 230 & 30 & 100 & 50 & 12.23 & 13.79 \\
\hline & \begin{tabular}{|c|} 
EBR \\
$100-\mathrm{N} 3.3-1$ \\
\end{tabular} & 34 & 12.5 & 3900 & 0.166 & 230 & 30 & 100 & 50 & 12.29 & 13.79 \\
\hline & \begin{tabular}{|c|} 
EBR \\
$100-N 3.3-2$
\end{tabular} & 38 & 12.5 & 3900 & 0.166 & 230 & 30 & 100 & 50 & 13.33 & 14.05 \\
\hline & \begin{tabular}{|c|} 
EBR \\
$100-N 4.5-2$ \\
\end{tabular} & 36 & 12.5 & 3900 & 0.166 & 230 & 30 & 100 & 50 & 14.18 & 13.91 \\
\hline & \begin{tabular}{|c|} 
EBR \\
$100-N 6.0-1$
\end{tabular} & 36 & 12.5 & 3900 & 0.166 & 230 & 30 & 100 & 50 & 13.71 & 13.91 \\
\hline
\end{tabular}

